\title{
TU/e emonownen

\section{Plasma-activated electrolysis for cogeneration of nitric oxide and hydrogen from water and nitrogen}

\section{Citation for published version (APA):}

Patel, H., Sharma, R. K., Kyriakou, V., Pandiyan, A., Welzel, S., van de Sanden, M. C. M., \& Tsampas, M. N. (2019). Plasma-activated electrolysis for cogeneration of nitric oxide and hydrogen from water and nitrogen. ACS Energy Letters, 4(9), 2091-2095. https://doi.org/10.1021/acsenergylett.9b01517

DOI:

10.1021/acsenergylett.9b01517

Document status and date:

Published: 13/09/2019

\section{Document Version:}

Accepted manuscript including changes made at the peer-review stage

\section{Please check the document version of this publication:}

- A submitted manuscript is the version of the article upon submission and before peer-review. There can be important differences between the submitted version and the official published version of record. People interested in the research are advised to contact the author for the final version of the publication, or visit the $\mathrm{DOI}$ to the publisher's website.

- The final author version and the galley proof are versions of the publication after peer review.

- The final published version features the final layout of the paper including the volume, issue and page numbers.

Link to publication

\section{General rights}

Copyright and moral rights for the publications made accessible in the public portal are retained by the authors and/or other copyright owners and it is a condition of accessing publications that users recognise and abide by the legal requirements associated with these rights.

- Users may download and print one copy of any publication from the public portal for the purpose of private study or research.

- You may not further distribute the material or use it for any profit-making activity or commercial gain

- You may freely distribute the URL identifying the publication in the public portal.

If the publication is distributed under the terms of Article 25fa of the Dutch Copyright Act, indicated by the "Taverne" license above, please follow below link for the End User Agreement:

www.tue.nl/taverne

Take down policy

If you believe that this document breaches copyright please contact us at:

openaccess@tue.nl

providing details and we will investigate your claim. 


\title{
Plasma activated electrolysis for cogeneration of
}

\section{nitric oxide and hydrogen from water and nitrogen}

\author{
Hrishikesh Patel ${ }^{a, 1}$, Rakesh K. Sharma ${ }^{a, 1}$, Vasileios Kyriakou ${ }^{a}$, Arunkumar Pandiyan $^{a}$, Stefan \\ Welzel $^{a}$, Mauritius C.M. van de Sanden ${ }^{a, b}$, Mihalis N. Tsampas ${ }^{a, *}$
}

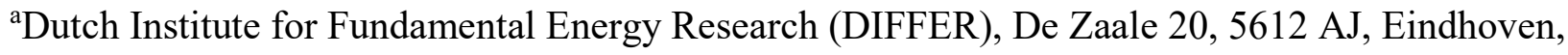
the Netherlands

${ }^{b}$ Department of Applied Physics, Eindhoven University of Technology (TU.e), 5600 MB, Eindhoven, the Netherlands

\section{Corresponding Author}

* Mihalis N. Tsampas. Email m.tsampas@differ.nl, Phone +31403334820

\section{ABSTRACT}

With increasing global interest in renewable energy technology in the backdrop of climate change, storage of electrical energy has become particularly relevant. Most sustainable technologies (e.g. wind, solar) produce electricity intermittently. Thus, converting electrical energy and base molecules (i.e. $\mathrm{H}_{2} \mathrm{O}, \mathrm{N}_{2}$ ) into energy rich ones (e.g. $\mathrm{H}_{2}, \mathrm{NH}_{3}$ ) or chemical feedstock (e.g. NO) is of paramount importance. While $\mathrm{H}_{2} \mathrm{O}$ splitting is compatible with renewable electricity, $\mathrm{N}_{2}$ fixation is currently dominated by thermally activated processes. In this work, we demonstrate an all-electric route for simultaneous $\mathrm{NO}$ and $\mathrm{H}_{2}$ production. In our approach, $\mathrm{H}_{2} \mathrm{O}$ is reduced to $\mathrm{H}_{2}$ in the cathode of a solid oxide electrolyser while NO is produced in the anode by the reaction of $\mathrm{O}^{2-}$ species (transported via the electrolyte) and plasma activated $\mathrm{N}_{2}$ species. High faradaic 
efficiencies up to $93 \%$ are achieved for NO production at $650{ }^{\circ} \mathrm{C}$ and $\mathrm{NO}$ concentration is $>1000$ times higher than the equilibrium concentration at same temperature and pressure.

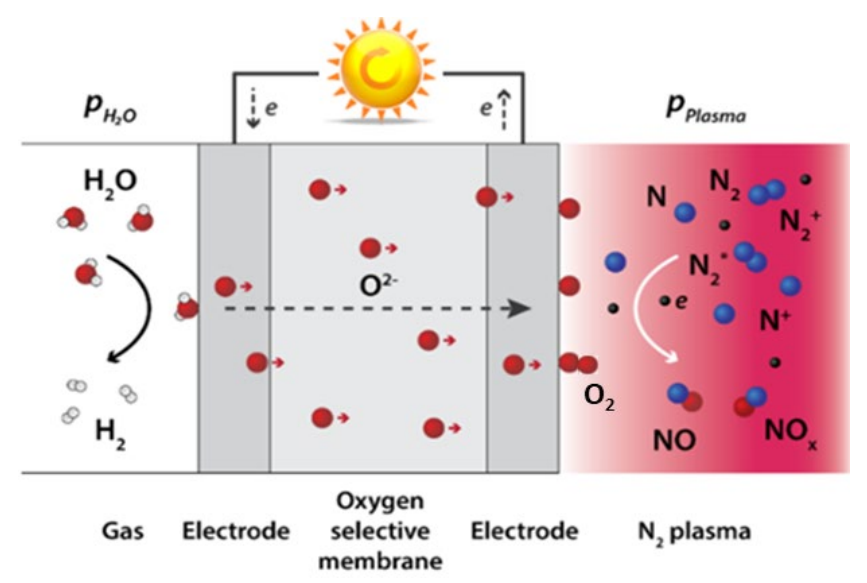

One of the greatest challenges of our era is the substitution of fossil feedstock as energy sources with renewable energy ones. However, due to their intermittent nature and the harvesting in the form of electricity, their direct introduction into the value chain of e.g. chemical industry remains challenging. Therefore, technologies based on renewable electricity that can transform base molecules (i.e. $\mathrm{H}_{2} \mathrm{O}, \mathrm{N}_{2}, \mathrm{CO}_{2}$ ) into energy or chemical rich ones have attracted tremendous interest [1-3]. In the transition from low to high energy molecules or to valuable chemical feedstock (e.g. $\mathrm{H}_{2}, \mathrm{NH}_{3}, \mathrm{CO}, \mathrm{NO}$ ), the activation of chemical bonds (e.g. $\mathrm{N} \equiv \mathrm{N}, \mathrm{O}=\mathrm{C}=\mathrm{O}$ ) is a major issue that has to be addressed [1-3].

Among the three base molecules, $\mathrm{N}_{2}$ is by far the least reactive since the $\mathrm{N} \equiv \mathrm{N}$ triple bond is very strong and difficult to activate due to the absence of a permanent dipole [4]. Consequently, even with the best available catalysts, a substantial energy input is required to activate $\mathrm{N}_{2}$. At industrial level nitrogen fixation is realized via ammonia and nitric oxide synthesis [5-8].

In the Haber-Bosch (HB) synthesis of ammonia, heterogeneous Fe- or Ru-based catalysts are used at temperatures from 400 to $500^{\circ} \mathrm{C}$ in order to cleave the $\mathrm{N} \equiv \mathrm{N}$ bond and convert $\mathrm{N}_{2}$ and $\mathrm{H}_{2}$ to $\mathrm{NH}_{3}$ 
at realistic rates. In this temperature range, the $\mathrm{NH}_{3}$ yield is very low at atmospheric pressure due to thermodynamic limitations and thus HB synthesis is carried out at 100-250 bar for shifting the equilibrium towards ammonia synthesis [5]. For a fully optimized and integrated HB process energy efficiencies as low as $0.48 \mathrm{MJ} / \mathrm{N}-\mathrm{mol}$ are reported [5].

$\mathrm{N}_{2}$ fixation can also occur in the form of nitric oxide (NO) which is a valuable chemical feedstock due to its commercial relevance especially for use in fertilizers, synthetic fibers, plastics and in drugs for cancer or inflammatory disorders [7-10]. NO is an intermediate in the industrial production of nitric acid, one of the basic industrial chemicals with annual world production of about 60 million metric ton/year [10].

Most of today's synthetic $\mathrm{NO}$ is made by oxidizing ammonia, while $\mathrm{NO}$ formation in $\mathrm{N}_{2}$ and $\mathrm{O}_{2}$ atmosphere takes place at high temperatures $\left(>2000^{\circ} \mathrm{C}\right)[7,8]$. Both processes are based on thermal catalysis with a significant $\mathrm{CO}_{2}$ footprint and thus electrification of $\mathrm{N}_{2}$ fixation is highly desirable and remains one of the biggest challenges.

Gas discharges are electrically driven processes and are easy to combine with intermittent electricity because of their fast response times. A gas discharge (plasma) is an ionized gas and represents a reactive environment due to the presence of charges, excited species and radicals. Plasmas are reported as one of the most promising approaches for the activation of $\mathrm{N} \equiv \mathrm{N}$ bond [1114]. Particularly, nitrogen plasmas produced by high or radio frequency (RF) sources at reduced pressures are well-known for efficiently producing vibrationally excited molecules which further dissociate into atomic nitrogen [15-17]. The relative concentration of the latter species in the afterglow of the plasma might be as high as $1000 \mathrm{ppm}[17]$.

Plasma based processes have gained a lot of attention for $\mathrm{N}_{2}$ fixation, starting from the oldest electric arc based Birkeland-Edye process [18] to different types of plasmas and reactor 
configurations [19-23]. Moreover, the combination of gas discharges with catalytic materials has been studied and reported for various catalysts and catalyst supports [24-29]. In the same context the tremendous enabling potential of (e.g. nitrogen) plasmas in combination with poor activity catalysts in conventional thermal catalysis has been demonstrated [13,29]. Recently, the combination of a plasma with aqueous or polymer electrolyte based electrochemical systems has been reported [30,31]. Nevertheless, to the best of our knowledge no such effort has been attempted for $\mathrm{NO}$ synthesis by $\mathrm{N}_{2}$ and $\mathrm{H}_{2} \mathrm{O}$.

In this work, we demonstrate a novel approach for the cogeneration of $\mathrm{NO}$ and $\mathrm{H}_{2}$ from $\mathrm{H}_{2} \mathrm{O}$ and plasma activated $\mathrm{N}_{2}$ gas using a hybrid plasma activated solid oxide electrolysis cell (SOEC). The novelty is related to the fact that the plasma activated nitrogen species are generated separately from the oxygen species: the oxygen to form NO is only provided through solid oxide membrane contacting the downstream part of a $\mathrm{N}_{2}$ plasma. The oxygen ions permeating the membrane is produced during water reduction to $\mathrm{H}_{2}$ in the cathodic compartment (which is isolated from the anodic one with a tubular electrolyte membrane). This setup therefore co-generates the products, $\mathrm{NO}$ and $\mathrm{H}_{2}$ in an integrated electrically driven way in two isolated compartments i.e. $\mathrm{NO}$ in the plasma compartment and $\mathrm{H}_{2}$ in the inner compartment (cf. Figure 1 for details). The main focus of the work is in the NO production however it is worthwhile to note that hydrogen is also a commercially viable compound in addition to being a topic of research for the hydrogen economy. Also note that the separation of the products $\left(\mathrm{NO}\right.$ and $\left.\mathrm{H}_{2}\right)$ from their corresponding gas streams, i.e. $\mathrm{N}_{2}$ and $\mathrm{H}_{2} \mathrm{O}$ respectively, can be easily realized nowadays by standard processes (i.e. adsorption and condensation [32]).

Our hybrid reactor (Figure 1) consists of an inductive coil which is connected to the matching network of a RF power supply. The coil encloses a quartz tube that is mounted on both ends to two 
vacuum flanges. These flanges serve as mechanical support for both the quartz tube and the tubular solid oxide electrolysis cell (SOEC) and provide electrode connections with the external circuit. In what follows we refer to the inner volume of the tubular SOEC as inner compartment while the active and passive zone of the plasma in the quartz tube is referred to as plasma compartment. The reactor is equipped with two inlets (for $\mathrm{H}_{2} \mathrm{O}$ and $\mathrm{N}_{2}$ ) and two outlets one for each compartment (Figure 1). The SOEC is based on an oxygen ion conducting tubular membrane (made from yttria stabilized zirconia, YSZ) with one end closed on which porous Pt films (Figure S1) have been deposited on both sides of the tube. As depicted in the inset of Figure 1, the inner one serves as a cathode (counter-electrode) while the outer as an anode (plasma-electrode). $\mathrm{H}_{2} \mathrm{O}$ is fed in the inner compartment ( 1 bar) of the tubular cell while $\mathrm{N}_{2}$ is used as feed gas in the plasma compartment (5 mbar) where activation takes place by the RF plasma source.

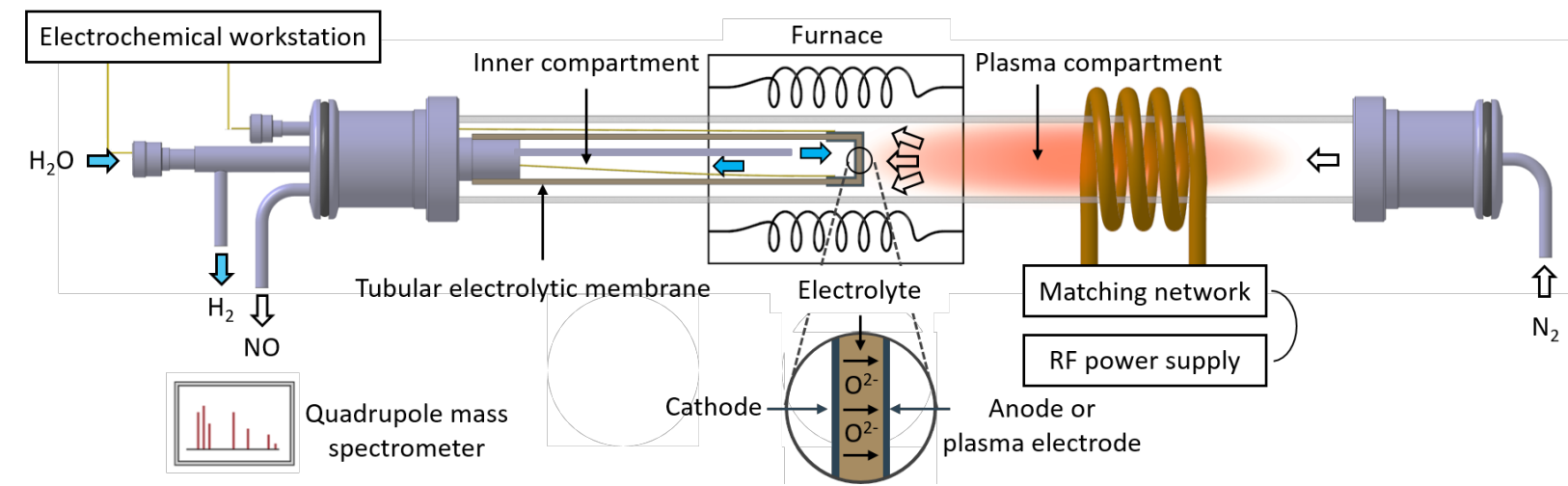

Figure 1: Schematic representation of hybrid plasma activated solid oxide electrolyte cell (SOEC) reactor setup.

Figure 2 depicts schematically the electrochemical reactions in each compartment under conventional and plasma activated SOEC operation. In both cases water reduction to hydrogen takes place in the cathode (inner compartment) with the simultaneous generation of oxygen ions (eq.1) on the triple phase boundaries (TPB), defined as the region where electrolyte (YSZ), gas, and catalyst (Pt) regions contact. These oxygen ions under the load (positive potential at anode) 
move from the point of generation to anode through electrolyte (YSZ: $\mathrm{O}^{2-}$ ionic conductor), where depending upon the SOEC operation, two competing reactions can take place. In conventional SOEC operation oxygen evolution reaction is predominant (eq.2) while in plasma activated SOEC operation, oxygen species can react with activated nitrogen (noted as $\mathrm{N}_{\mathrm{x}}{ }^{*}$ ) for the formation of nitric oxides (eq.3). The latter reaction is the key novelty of this contribution.

Cathode: $\quad 2 \mathrm{H}_{2} \mathrm{O}+4 \mathrm{e}^{-} \rightarrow 2 \mathrm{H}_{2}+2 \mathrm{O}^{2-}(\mathrm{YSZ})$

Anode: $\quad$ Plasma OFF: 2O- $\mathrm{O}^{2-}(\mathrm{YSZ})+\mathrm{N}_{2} \rightarrow \mathrm{O}_{2}+\mathrm{N}_{2}+4 \mathrm{e}$

Plasma ON: $\mathrm{xO}^{2-}(\mathrm{YSZ})+\mathrm{N}_{\mathrm{x}}{ }^{*} \rightarrow \mathrm{xNO}+2 \mathrm{xe}^{-}$

Conventional SOEC electrolysis

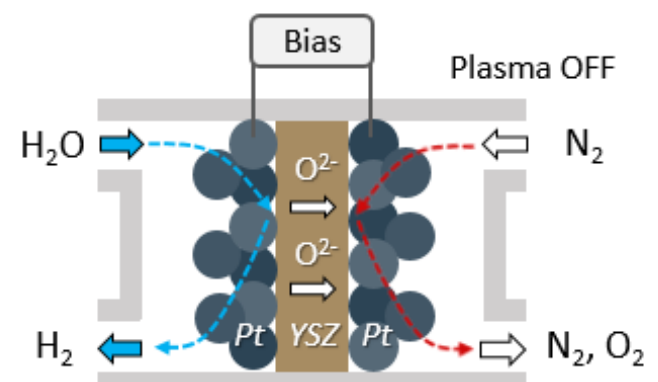

Cathodic half reaction: Anodic half reaction:

$\mathrm{H}_{2} \mathrm{O}+2 e^{-} \rightarrow \mathrm{H}_{2}+\mathrm{O}^{2-} \quad \mathrm{O}^{2-} \rightarrow 1 / 2 \mathrm{O}_{2}+2 e^{-}$
Plasma activated SOEC electrolysis

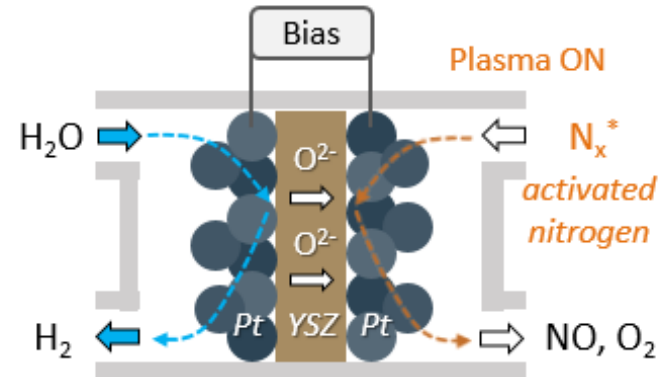

Cathodic half reaction: Anodic half reactions:

$\mathrm{H}_{2} \mathrm{O}+2 e^{-} \rightarrow \mathrm{H}_{2}+\mathrm{O}^{2-}$
$\mathrm{O}^{2-} \rightarrow \frac{1}{2} \mathrm{O}_{2}+2 e^{-}$ $x O^{2-}+N_{x}^{*} \rightarrow x N O+2 x e$

Figure 2: Operation principles of conventional (left) and activated (right) SOEC electrolysis.

Unlike conventional plasma catalysis, that requires the co-activation of reactants, our unique approach ensures that all the energy of the plasma is directed towards activating the nitrogen. Therefore, this 'dual chamber' approach has the inherent advantage of separating both the reactants and the most important process steps in space, namely, the activation or dissociation of the base molecules and the formation of products, respectively. 
Figure 3 depicts the production rate of $\mathrm{NO}, \mathrm{O}_{2}$ and $\mathrm{H}_{2}$ at $650{ }^{\circ} \mathrm{C}$ upon step change in the applied current $(20 \mathrm{~mA})$ and plasma $(80 \mathrm{~W})$ sequentially. In order to perform this experiment under conditions of fixed $\mathrm{O}^{2-}$ fluxes, water splitting has been carried out at $20 \mathrm{~mA}$ applied current (i.e. galvanostatic mode). $\mathrm{NO}, \mathrm{O}_{2}$ and $\mathrm{H}_{2}$ were measured using a quadrupole mass spectrometer. Under open-circuit $(I=0)$ and plasma off conditions, no reaction takes place in either compartments. Upon applying current at $t=10 \mathrm{~min},(I=20 \mathrm{~mA})$ in the absence of plasma leads to only water electrolysis, producing hydrogen $\left(\sim 104 \mathrm{nmol} \mathrm{H}_{2} / \mathrm{s}\right)$ and oxygen $\left(\sim 50 \mathrm{nmol} \mathrm{O}_{2} / \mathrm{s}\right)$ in the two chambers. The rate of hydrogen production is double the rate of oxygen production without plasma as stoichiometrically expected whilst no $\mathrm{NO}_{x}$ (i.e. $\mathrm{NO}, \mathrm{NO}_{2}$ or $\mathrm{N}_{2} \mathrm{O}$ ) synthesis has been observed. Thus, there is no electrochemical $\mathrm{NO}_{\mathrm{x}}$ synthesis. Upon plasma ignition at $t=20 \mathrm{~min}, \mathrm{NO}$ formation starts taking place with a simultaneous decrease of the oxygen evolution and a steady state is reached after $\sim 2 \mathrm{~min}$. Rate of $\mathrm{NO}$ production $(63 \mathrm{nmol} \mathrm{NO} / \mathrm{s})$ is roughly double the rate of oxygen consumption $(31 \mathrm{nmol} \mathrm{O} / \mathrm{s})$ which is consistent with reaction stoichiometry.

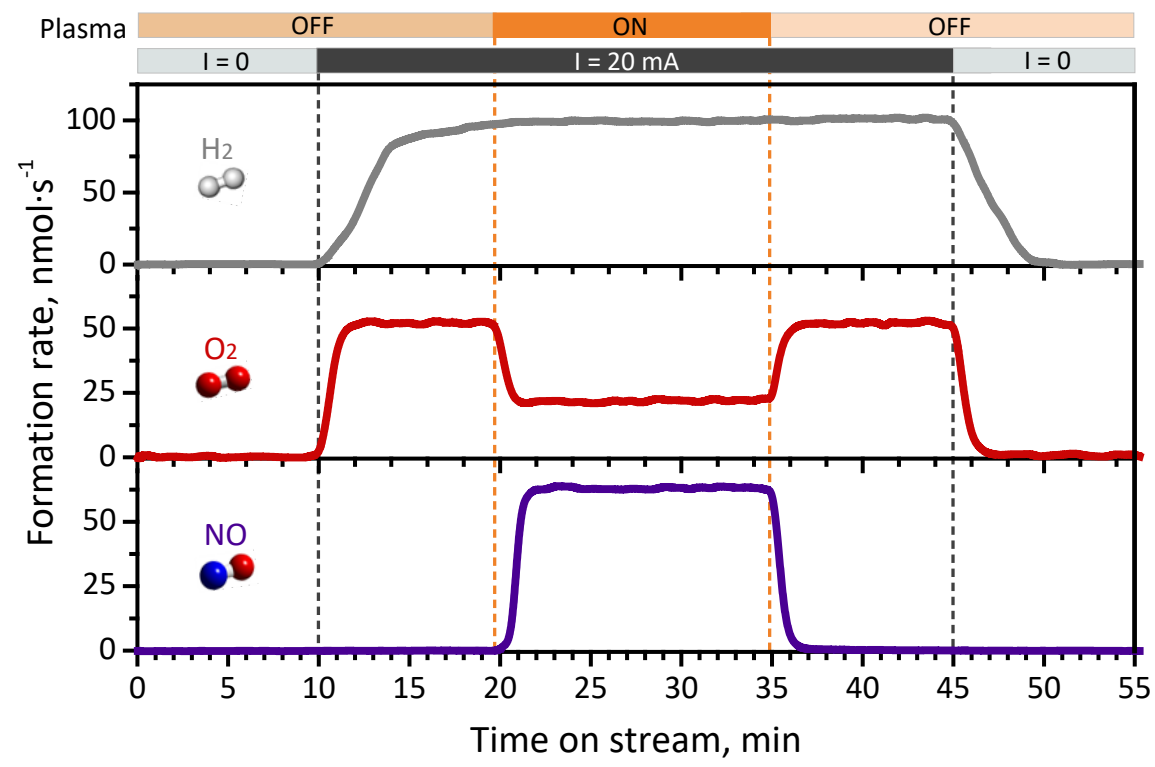

Figure 3: Production rate of $\mathrm{NO}, \mathrm{O}_{2}$ and $\mathrm{H}_{2}$ at $650{ }^{\circ} \mathrm{C}$ upon sequential step changes of the applied current $(20 \mathrm{~mA})$ and the plasma $(80 \mathrm{~W})$. 
Moreover, except $\mathrm{NO}$, no other products such as $\mathrm{NO}_{2}$ and $\mathrm{N}_{2} \mathrm{O}$ were observed throughout the experiment. Once plasma is switched off at $t=35 \mathrm{~min}$, the NO production rate gradually returns to zero, while $\mathrm{O}_{2}$ formation returns to its initial value. By current interruption at $t=45 \mathrm{~min}, \mathrm{H}_{2}$ and $\mathrm{O}_{2}$ signals drop to zero. In essence, as shown by this transient experiment, the selective production of $\mathrm{NO}(63 \mathrm{nmol} \mathrm{NO} / \mathrm{s})$ without the formation of other byproducts occurs only in the presence of plasma verifying that it is clearly plasma activated process.
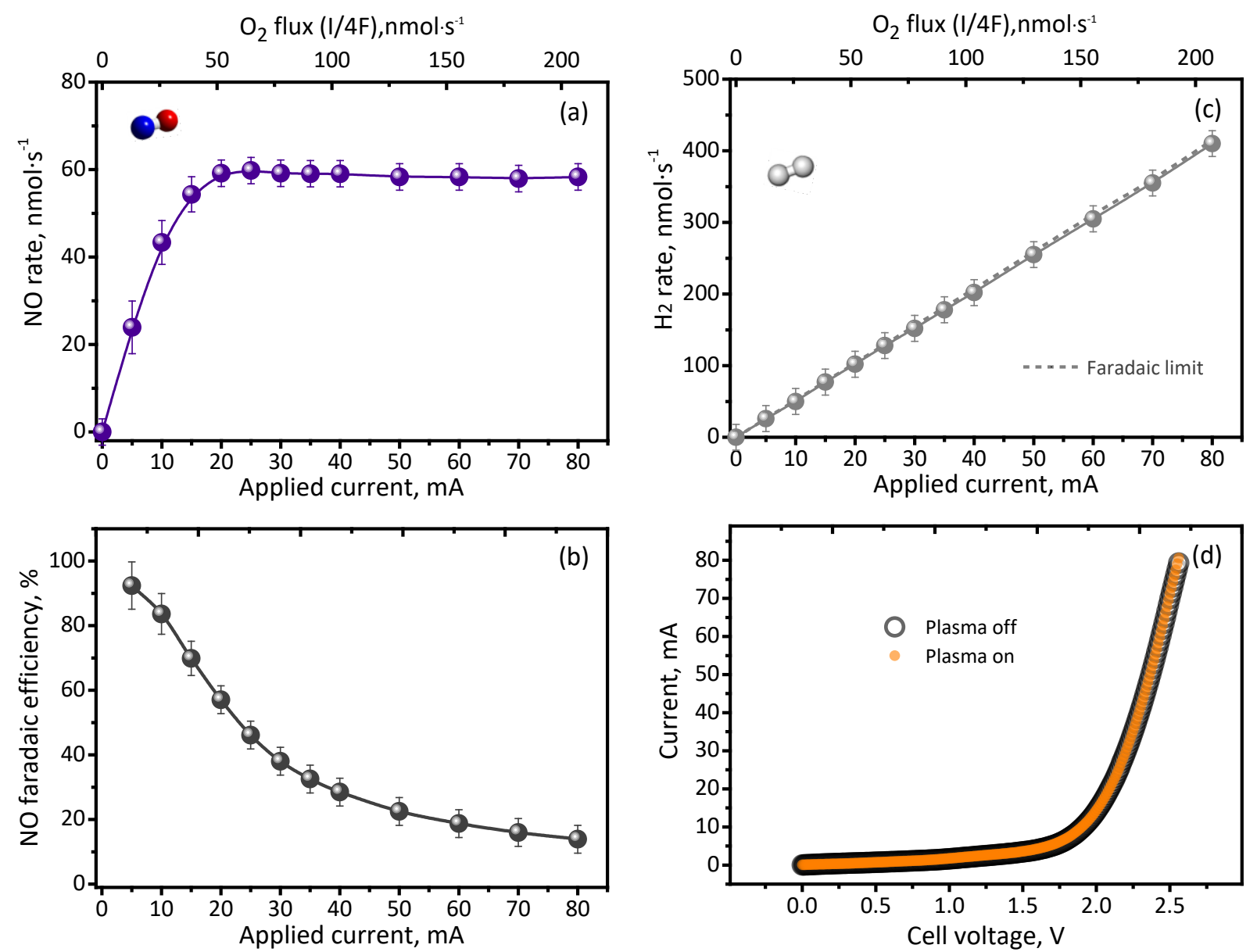

Figure 4: Effect of current on the rate of $\mathrm{NO}$ (a) and $\mathrm{H}_{2}$ (b) production (c) faradaic efficiency of NO production and (d) Pt/YSZ/Pt cell voltage (black open symbols correspond to normal SOEC operation while orange filled symbols to plasma activated one). 
Figure $4 \mathrm{a}$ depicts the effect of applied current under plasma activated nitrogen on the production rate of NO. Upon current application, oxygen ions arriving on the Pt/YSZ interface are diffused on the catalyst surface as adsorbates, where they can either react with activated nitrogen species for NO formation or with co-adsorbed oxygen species for the formation of molecular oxygen. At low current range $(<20 \mathrm{~mA})$ a linear increase of NO production with the applied current is observed, since the reaction is limited by the supply of oxygen species. In electrochemical cells, the reaction zone is limited in the vicinity of the triple (gas-catalyst-electrolyte) phase boundary. At higher currents NO formation reaches a saturation value which can be attributed to limited supply of activated nitrogen species on the TPB area and the higher driving force for oxygen evolution reaction. Both are strongly related to the microstructural properties of the catalyst (plasma electrode) such as porosity, particle size, tortuosity etc. (Figure S1). This assumption is consistent with the observed faradaic efficiency (i.e. the conversion of oxygen to nitric oxide) which starts from $93 \%$ and gradually decreases with increasing current (Figure 4b). The corresponding conversion of nitrogen to nitric oxide is $0.045 \%$ at $20 \mathrm{~mA}$.

Although the available experimental data for our hybrid plasma activated SOEC system do not yet allow for a detailed description of the key species and the involved reaction mechanisms, a straightforward qualitative hypothesis is presented in what follows. In the afterglow of RF nitrogen plasmas (e.g. [17]) a relative concentration of $0.1 \%$ atomic nitrogen, $\mathrm{N}$, is found. Highly vibrationally excited nitrogen molecules $\mathrm{N}_{2}$ ( $\mathrm{v}>13$ ) and long-living metastable molecules, $\mathrm{N}_{2}(A)$, are a factor 10 and $10^{-4}$ less abundant than $\mathrm{N}$. Assuming the same relative concentration of $\mathrm{N}$ would lead under the present experimental conditions to a flux of atomic nitrogen species impinging onto surface of the electrochemical cell of about $\left(\sim 1.5 \times 10^{16} \mathrm{~s}^{-1}\right)$, thereby considering an ideally flat electrode surface. The flux of oxygen ions through the membrane is of the same order of magnitude 
$\left(<6 \times 10^{16} \mathrm{~s}^{-1}\right.$ equivalent to twice the value of $50 \mathrm{nmol} / \mathrm{s}$ as reported for $20 \mathrm{~mA}$ in Figure 3). At this current level further NO formation would be hampered by the availability of atomic nitrogen and the NO formation rate levels off. This qualitative picture still entirely neglects the flux of vibrationally excited nitrogen molecules from the afterglow, recombination of atomic nitrogen species on the surface and kinetic effects which will be subject to further research efforts. Nevertheless, especially under the low pressure conditions in the plasma compartment it is safe to assume that the oxidation of plasma-activated nitrogen species impinging on the TPB is the key mechanism of NO formation. In the absence of plasma NO formation has not been observed (Figure 3) which highlights the need of the plasma-activation step.

By modestly changing the plasma power the impinging flux of activated nitrogen is modified which should affect the NO formation rate. In Figure S2 the effect of plasma power on the NO production is shown. At the three examined conditions a similar behavior is observed i.e. NO production increases in the low current range followed by a plateau at higher current values. Upon increasing plasma power more activated nitrogen species are generated and become available at the TPBs and thus leading to higher NO formation rates at the same current levels. The observed behavior of NO formation rates as function of applied plasma power are consistent with our aforementioned hypothesis about the main reaction mechanisms. Therefore, a detail study of effect of TBP, electrode thickness as well as plasma characteristics will be required to further elucidate this point and it will be the topic of a future work.

Interestingly, the amount of NO produced is more than 3 orders of magnitude higher than the equilibrium concentration of the $\mathrm{NO}$ in a $\mathrm{N}_{2}, \mathrm{O}_{2}, \mathrm{NO}$ mixture at this temperature and concentration (Figure S3, top). Similar levels of NO concentration at equilibrium can be only achieved at operating temperature in the range of $1600-1800{ }^{\circ} \mathrm{C}$ (Figure S3, bottom). 
An important and unique feature of our concept is that apart from nitrogen fixation at the anode, hydrogen is also produced at the cathode as a result of water reduction. The hydrogen production as a function of applied current is shown in Figure 4c. Moreover, due to our reactor configuration plasma active area is far from the catalyst so the SOEC polarization curve (Figure 4d) as well as the electrochemical impedance spectra (Figure S4) are not affected.

This contribution serves as a proof of principle demonstrating that plasma activated gas can be implemented in electrochemical systems. The energy consumption in our system is $1350 \mathrm{MJ} / \mathrm{N}$ mol which is within the range of reported values (47 to $2698 \mathrm{MJ} / \mathrm{N}-\mathrm{mol}$ ) for $\mathrm{N}_{2}$ fixation by $\mathrm{H}_{2} \mathrm{O}$ [19-22]. It should be emphasized that there is plenty room of improvement by utilizing advanced SOEC catalyst architectures [33] and adjusting operational parameters.

We have demonstrated that surface generated oxygen by means of a solid oxide electrolyte membrane is reacted with activated nitrogen gas for the first time, paving the way for an innovative all electric nitrogen fixation pathway. It is worthwhile to note the counter product of the electrolysis reaction i.e. hydrogen is also a commercially viable compound in addition to being a topic of research for the hydrogen economy.

\section{EXPERIMENTAL}

The setup, consists of mainly an RF generator $(13.56 \mathrm{MHz}, 300 \mathrm{~W}$ maximum power rating Huttinger PFG $300 \mathrm{RF}$ ) with a coil enclosing a quartz tube of $40 \mathrm{~mm}$ outer diameter and $700 \mathrm{~mm}$ length, called plasma reactor and a SOEC inside the quartz tube, as shown in Figure 1. To couple an atmospheric pressure process (water splitting) with a vacuum process $\left(\mathrm{N}_{2}\right.$ activation by $\mathrm{RF}$ plasma), we chose to use a tubular ceramic (YSZ) electrolyte. This tubular electrolyte was required 
for supporting mechanically its own weight, thus we implemented a commercially available YSZ tube with thick walls (Ortech, $2 \mathrm{~mm}$ thickness, $25 \mathrm{~mm}$ diameter and $245 \mathrm{~mm}$ length). Inner compartment of the SOEC is at 1 bar whereas the plasma compartment is at 5 mbar. Pt electrodes were deposited by brush painting (organometallic paste, Fuel Cell Materials) on both sides of the closed end of YSZ tube and consequently annealed at $900{ }^{\circ} \mathrm{C}(2 \mathrm{~h})$ in air. The electrode surface area is around $20 \mathrm{~cm}^{2}$, while the loading is $5 \mathrm{mg}$ of Pt per $\mathrm{cm}^{2}$. The current densities we obtained are typical for SOEC with similar electrolyte/electrode combinations operating in similar conditions $[34,35]$.

The surface morphology of the Pt/YSZ interface was characterized using a scanning electron microscope (FEI Quanta 3D FEG instrument) at an acceleration voltage of 3-5 keV and a working distance of $10 \mathrm{~mm}$. The electrochemical characterization was carried out using a CompactStat (Ivium) potentiostat.

Humidified $\mathrm{He}(50 \mathrm{ml} / \mathrm{min})$ was used in the cathodic compartment at atmospheric pressure while at fixed nitrogen flow $(100 \mathrm{ml} / \mathrm{min})$ was fed in plasma compartment at 5 mbar pressure. The experiments were performed at $650{ }^{\circ} \mathrm{C}$ for three different values of applied input power $(40,60$ and $80 \mathrm{~W}$ ) while maintaining $0 \mathrm{~W}$ reflected power through a tunable matching network.

The gases from the electrochemical cell and plasma reactor were analyzed using a Hiden Analytical Quadrupole Mass Spectrometer HAL 201RC. The calibrations to quantify the NO and $\mathrm{H}_{2}$ production and $\mathrm{O}_{2}$ consumption were carried out by using 100 ppm $\mathrm{NO}$ in $\mathrm{He}, 1 \% \mathrm{H}_{2}$ in $\mathrm{He}$ and $1 \% \mathrm{O}_{2}$ in $\mathrm{He}$ cylinders, respectively. In each case, the standard gas mixture was used without dilution and with He dilution in the levels of $25 \%$ and $50 \%$ keeping the flow rate constant, e.g. for NO, $100 \mathrm{ppm}, 75 \mathrm{ppm}$ and $50 \mathrm{ppm} \mathrm{NO}$ in He was used for the calibration. In all the cases, a linear 
relation between the signal level and amount of the gas in study, has been observed. $\mathrm{NO}$ and $\mathrm{H}_{2}$ co-generation experiments were repeated three times.

Thermodynamic calculations for the equilibrium concentration of $\mathrm{NO}$ in a $\mathrm{N}_{2}, \mathrm{O}_{2}$, $\mathrm{NO}$ gas mixture were performed using HSC Chemistry (Outotec Technologies).

\section{ASSOCIATED CONTENT}

\section{Supporting Information}

The Supporting Information is available free of charge on the ACS Publications website at DOI: XXXX. This file contains microstructural characterization of Pt/YSZ interface, effect of current and plasma power on the $\mathrm{NO}$ production, equilibrium concentration of $\mathrm{NO}$ as a function of the $\mathrm{O}_{2}$ concentration at $650{ }^{\circ} \mathrm{C}$, and Nyquist plot of $\mathrm{Pt} / \mathrm{YSZ} / \mathrm{Pt}$ at $\mathrm{OCV}$ with and without plasma.

\section{AUTHOR INFORMATION}

Corresponding Author: Mihalis N. Tsampas.

Email $\underline{\text { m.tsampas@differ.nl, }}$ Phone +31403334820

${ }^{1}$ First and second authors contributed equally to the article.

The authors declare no competing financial interest.

\section{ACKNOWLEDGMENT}

This project has been co-financed by TKI-Energie from Toeslag voor Topconsortia voor Kennis en Innovatie (TKI) from the Ministry of Economic Affairs and Climate Policy. The authors would like to thank E. Langereis (DIFFER) and B. Lamers (DIFFER) for help with the illustrations and 
H. Dzafic (TU.e) for his contribution in completing the setup. ISPT, University of Twente, Nouryon, OCI Nitrogen, Vopak and Yara are also acknowledged for their support in the project.

\section{REFERENCES}

[1] Gur, T. M., Review of electrical energy storage technologies, materials and systems: challenges and prospects for large-scale grid storage. Energy Environ. Sci. 11, 2696-2767 (2018).

[2] Schiffer, Z. J. and Manthiram, K., Electrification and Decarbonization of the Chemical Industry. Joule 1, 10-14 (2017).

[3] Kyriakou, V., Garagounis, I., Vasileiou, E., Vourros, A. \& Stoukides, M. Progress in the Electrochemical Synthesis of Ammonia. Catal. Today 286, 2-13 (2017).

[4] van der Ham, C. J. M., Koper, M. T. M. \& Hetterscheid, D. G. H. Challenges in reduction of dinitrogen by proton and electron transfer. Chem. Soc. Rev. 43, 5183-5191 (2014).

[5] Liu, H., Ammonia synthesis catalyst 100 years: Practice, enlightenment and challenge. Chin. J. Catal. 35, 1619-1640 (2014).

[6] Marnellos, G. and Stoukides, M., Ammonia synthesis at atmospheric Pressure. Science 282, 98-100 (1998).

[7] Patil, B.S., Wang, Q., Hessel, V., Lang, J., Plasma N2-fixation: 1900-2014. Catal. Today 256, 49-66 (2015).

[8] Patil, B.S., Peeters, F.J.J., Medrano, J.A., Gallucci, F., van Rooij, G., Lang, J., Wang, Q., Hessel, V., Plasma assisted nitrogen oxide production from air: Using pulsed powered gliding arc reactor for a containerized plant. AIChE Journa, 64, 526-537 (2018) 
[9] Opländer, C., Baschin, M., van Faassen, E.E., Born, M., Möller, M., Pallua, N., Suschek, C.V., A new method for sustained generation of ultra-pure nitric oxide-containing gas mixtures via controlled UVA-photolysis of nitrite solutions, Nitric Oxide, 23, 275-283 (2010)

[10] Thengane, S.K., Bandyopadhyay, S., Mitra, S., Bhattacharya, S., Hoadley, A., An alternative process for nitric oxide and hydrogen production using metal oxides, Chemical Engineering Research and Design, 112 (2016) 36-45

[11] Fridman, A. Plasma Chemistry. (Cambridge University Press, 2008). doi:DOI: $10.1017 / \mathrm{CBO} 9780511546075$

[12] Utz, A. L. Vibrations that live long and prosper. Nat. Chem. 10, 577-578 (2018).

[13] Mehta P., Barboun P., Go, D.B., Jason C. Hicks, J.C., Schneider, W.F., ACS Energy Lett. $4,5,1115-1133(2019)$

[14] Boagerts, A., Neyts, E.C., Plasma Technology: An Emerging Technology for Energy Storage, ACS Energy Lett., 3, 4, 1013-1027 (2018)

[15] Loureiro, J., Ferreira, C.M., Coupled electron energy and vibrational distribution functions in stationary N2 discharges J. Phys. D: Appl. Phys. 19, 17-35 (1986)

[16] Gorse, C., Cacciatore, M., Capitelli, M., De Benedicts, S., Dilecce, G., Electron energy distribution functions under N2 discharge and post-discharge conditions: a self-consistent approach, Chemical Physics, 119, 63-70 (1988)

[17] Ricard, A., Sarretter J.P., Jeon, B., Kim Y.K., Discharge source-dependent variation in the densities of active species in the flowing afterglows of N2 RF and UHF plasmas, Current Applied Physics, 17, 945-950 (2017) 
[18] Eyde, S., Oxidation of atmospheric nitrogen and development of resulting industries in Norway. J. Ind. Eng. Chem. 4, 771-774 (1912).

[19] Mizukoshi, Y., Katagiri, R., Horibe, H., Hatanaka, S., Asano, M., Nishimura, Y., Nitrogen fixation in an aqueous solution by a novel flow plasma system, Chem. Lett. 44, 495-496 (2015).

[20] Harada, K., Igari, S., Takasaki M., Shimoyama, A., Reductive fixation of molecular nitrogen by glow discharge against water, Journal of the Chemical Society, Chemical Communications, 17, 1384-1385 (1986).

[21] Bian, W., Shi, J., Yin, X., Nitrogen fixation into water by pulsed high-voltage discharge, IEEE Transactions on Plasma Science, 37(1), 211-218 (2009)

[22] Bian W., Song, X., Shi, J., Yin, X., Nitrogen fixed into $\mathrm{HNO}_{3}$ by pulsed high voltage discharge, J. Electrostat., 70, 317-326 (2012)

[23] Shmelev, V.M., Saveliev, A.V., Kennedy, L.A., Water Purification by Using Microplasma Treatment, Plasma Chem. Plasma Process. 2009, 29, 275-290.

[24] Whitehead, J.C., Plasma-catalysis: the known knowns, the known unknowns and the unknown unknowns. Journal of Physics D: Applied Physics, 49, 243001 (24 pp), (2016)

[25] Sun, Q., Zhu, A., Yang, X., Niu, J. \& Xu, Y. Formation of NOx from N2 and O2 in catalystpellet filled dielectric barrier discharges at atmospheric pressure. Chem. Commun. 1418$1419(2003)$

[26] Shah, J., Wang, W., Bogaerts, A., Carreon, M.L., Ammonia synthesis by radio frequency plasma catalysis: revealing the underlying mechanisms. ACS Applied Energy Materials, 1 (9) 4824-4839 (2018) 
[27] Patil, B.S., Cherkasov, N., Lang, J., Ibhadon, A.O., Hessel, V., Wang, Q., Low temperature plasma-catalytic NOx synthesis in a packed DBD reactor: Effect of support materials and supported active metal oxides. Appl. Catal. B Environ. 194, 123-133 (2016).

[28] Li., S., Medrano Jimenez, J.A., Hessel, V., Gallucci, F., Recent progress of plasma-assisted nitrogen fixation research: A review, Processes, 6248 (2018)

[29] Mehta, P., Barboun, P., Herrera F.A., Kim, J., Rumbach, P., Go, D.B., Hicks, J.C., Schneider, W.F. Overcoming ammonia synthesis scaling relations with plasma-enabled catalysis. Nat. Catal. 1, 269-275 (2018).

[30] Hawtof, R., Ghosh, S., Guarr, E., Xu, C., Sankaran R.M., Renner, J.N., Catalyst-free, highly selective synthesis of ammonia from nitrogen and water by a plasma electrolytic system. Sci. Adv. 5, eaat5778 (2019)

[31] Kumari, S., Pishgar, S., Schwarting, M. E., Paxton, W. F. \& Spurgeon, J. M. Synergistic plasma-assisted electrochemical reduction of nitrogen to ammonia. Chem. Commun. 54, $13347-13350$ (2018).

[32] Triebe, R.W., Tezel, F.H., Adsorption of nitrogen, carbon monoxide, carbon dioxide and nitric oxide on molecular sieves, Gas Separation \& Purification, 9(4) (1995) 223-230

[33] John T. S. Irvine, J.T.S., Neagu, D., Verbraeken, M.C., Chatzichristodoulou C., Graves, C., Mogensen, M.B., Evolution of the electrochemical interface in high-temperature fuel cells and electrolysers, Nature Energy, 1(1), 15014 (2016)

[34] Roche, V., Karoum. R., Billard, A. Revel, R., Vernoux, R., Electrochemical promotion of deep oxidation of methane on Pd/YSZ, J Appl Electrochem., 38 (2008) 1111-1119

[35] Vernoux, P., Lizarraga, L., Tsampas, M.N., Sapountzi, F.M., De Lucas-Consuegra, A., Valverde, J.L., Souentie, S., Vayenas, C.G., Tsiplakides, D., Balomenou, S., Baranova, E., 
Ionically conducting ceramics as active catalytic supports, Chemical Reviews, 113 (10) (2013) 8192-8260. 